\title{
Investigation of post-earthquake displacements in viaducts using Geodetic and Finite Element Methods
}

\author{
D. Güney ${ }^{1}$, M. Acar ${ }^{2}$, M. T. Özlüdemir ${ }^{3}$, and R. N. Çelik ${ }^{3}$ \\ ${ }^{1}$ Division of Structure, Department of Architecture, Faculty of Architecture, Yildiz Technical University, \\ 34469 Istanbul, Turkey \\ ${ }^{2}$ Division of Geodesy, Department of Geomatics Engineering, Faculty of Engineering, Aksaray University, \\ 68100 Aksaray, Turkey \\ ${ }^{3}$ Department of Geomatics Engineering, Faculty of Civil Engineering, Istanbul Technical University, \\ 34469 Maslak, Istanbul, Turkey
}

Received: 4 June 2010 - Revised: 29 October 2010 - Accepted: 24 November 2010 - Published: 15 December 2010

\begin{abstract}
This paper presents the results of research into the post-earthquake displacements of the partially constructed road viaducts in Bolu, Turkey after the Izmit/Kocaeli, $\left(M_{\mathrm{w}}=\right.$ 7.4), and Düzce $\left(M_{\mathrm{w}}=7.1\right)$ earthquakes on 17 August and 12 November 1999, respectively. The investigations on the viaducts were carried out using both Geodetic and Finite Element Methods (FEM). Firstly, all the geodetic network stations selected for the project were checked because of the recent deformation in the area. Then, new control stations were placed between the piers of the viaducts. 28 object points were placed and measured on each pier to determine their displacements. In the second stage, the behaviours of the viaducts were modelled using the FEM, and the Düzce earthquake acceleration record was analysed to observe the response of the viaducts in a time history domain. The modelled displacement response of the viaducts was compared with the geodetic measurements in order to interpret the sensitivity of the design calculation of the engineering model. The pier displacements that were geodetically measured and calculated using FEM peak pier displacements showed an increase in the piers located closer to the surface rupture from the Izmit/Kocaeli and Düzce earthquakes. The agreement between the observed and modelled displacements decreases with the increase in the distance from the fault line. Since, near the fault trace the horizontal displacement field is discontinuous and large inelastic deformation is expected, the behaviour of the part of the structure located near the fault line cannot be
\end{abstract}

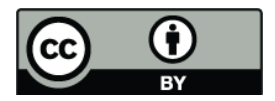

Correspondence to: M. Acar (acarmusta@gmail.com) easily reproduced by FEM simulations. This is because the applied model loads derived from the source acceleration spectra cannot be included in the localized finite deformation effects. In order to obtain an improved engineering analysis, it is necessary to utilise more parameters in the numerical analysis.

\section{Introduction}

One of the most destructive natural phenomena is a severe earthquake and its terrible after-effects (Çelik et al., 2004; Calvi et al., 2001; Ambraseys, 1988). In Turkey, because of the underlying tectonic structure (Armijo et al., 1999; Bozkurt, 2001) many regions are located in high risk earthquake zones (Ambraseys, 1999, 2002; Barka, 1996). The Izmit/Kocaeli, $\left(M_{\mathrm{w}}=7.4\right)$, and Düzce $\left(M_{\mathrm{w}}=\right.$ 7.1) earthquakes on 17 August and 12 November 1999, respectively, occurred on the North Anatolian Fault (NAF) (Akyüz, 2002; Barka, 1999; Tibi et al., 2001). Both earthquakes had a severe impact over a large area (Barka et al., 2000) causing substantial damage to one of the Bolu Viaducts and the Bolu Tunnel, which were under construction at the time (Barr et al., 2001). The damaged viaduct was almost complete at the time of the second earthquake in November 1999, but other Bolu Viaducts in the early stages of construction shown no visible signs of damage (Çelik et al., 2005).

The Bolu Viaducts are located close to the Düzce section of NAF, along which the Düzce earthquake took place. The Bolu Viaduct consists of two parallel bridges that carry east and westbound traffic (as shown in Fig. 1), and its purpose

Published by Copernicus Publications on behalf of the European Geosciences Union. 


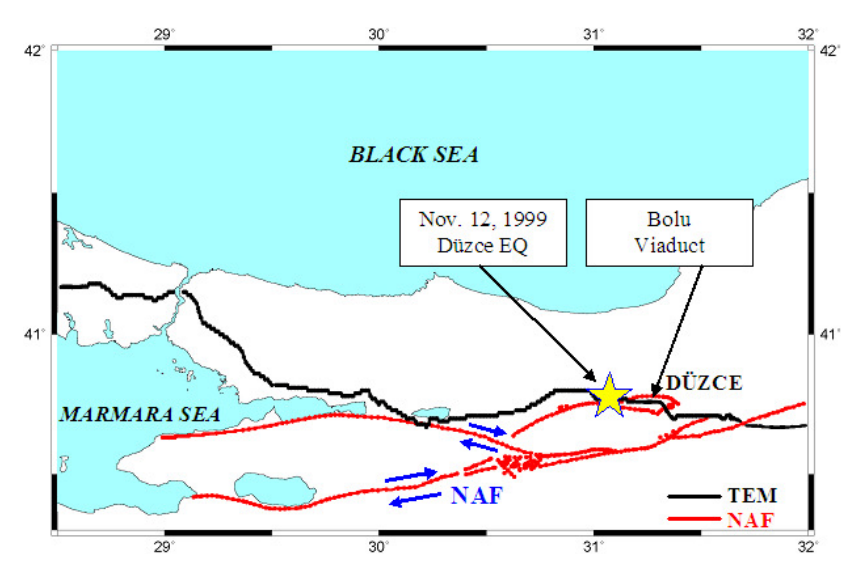

Fig. 1. North Anatolian Fault (NAF), Trans-European Motorway (TEM) from Ankara to Istanbul and the location of the Bolu Viaducts (GMT software, Wessel and Smith, 1991, 1995a, b, 1998).

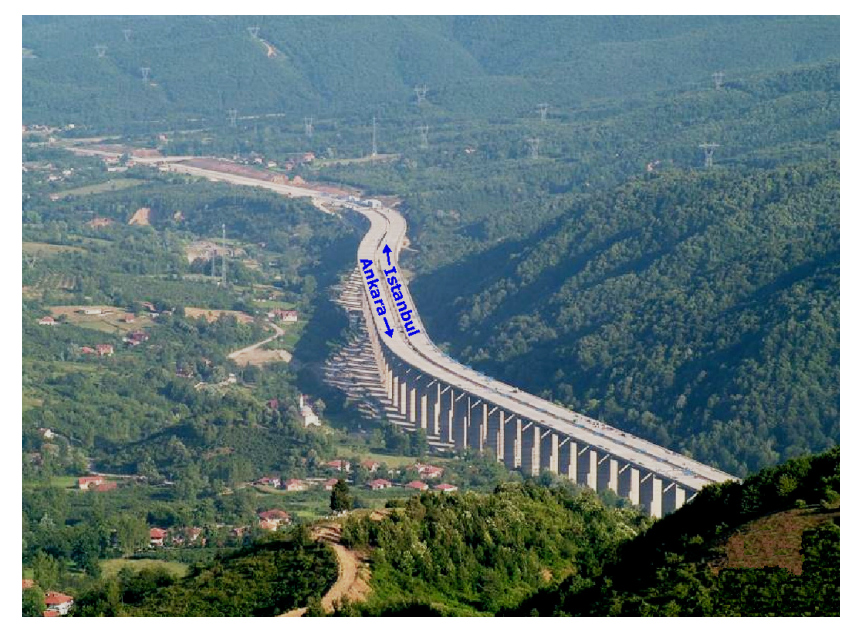

Fig. 2. General view of the Bolu Viaduct (modified from www.bolu.net, 2010).

is to connect the highway to the Bolu tunnel. The Bolu Viaducts and tunnel were designed by Paolo Versace and constructed by the Bayindir-Astaldi consortium. The general view of viaduct is shown in Fig. 2. After the large earthquakes in 1999, extensive damage was observed, Fig. 3a shows a dislodged damper and Fig. 3b shows transverse shear keys that were significantly damage during the earthquake however, there was no evidence of partial or total collapse.

The post and pre-earthquake geodetic displacement measurements of engineering structures have utmost importance for the future use of the structures. It is important, that not only such displacements, but also crustal movements that threaten settlements and the infrastructure in the region which should be determined precisely i.e. subcentimetre level using space geodetic measurements like Global Positioning System (GPS) (Çelik et al., 2004). Thus,

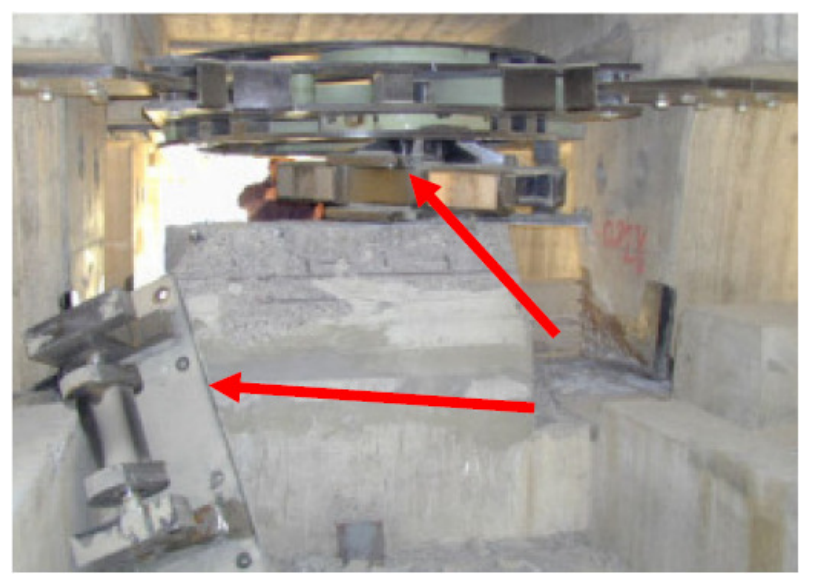

(a)

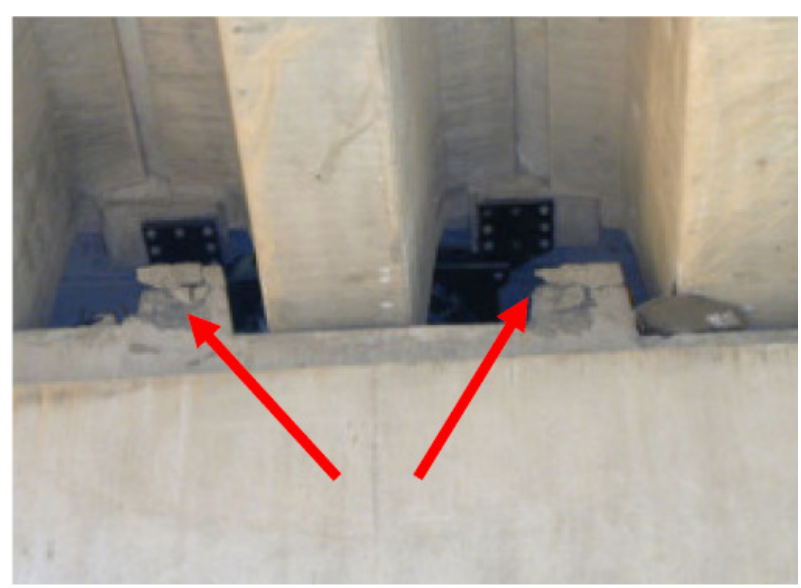

(b)

Fig. 3. Structural damage caused by the earthquake (a) dislodged damper (b) Movement in transverse shear keys (from Park et al., 2004).

the post-earthquake displacements of the Bolu viaducts were investigated by both geodetic techniques and the Finite Element Method (FEM).

In the first part of the research project the geodetic stations across the area surrounding the deformed viaducts were analyzed in terms of their viability for future use. Then, to establish the connections between control stations and object points and to analyse the damage caused by the earthquakes, all the points were re-measured using a space geodetic technique with GPS receivers, total stations and precise levels. Hence, new coordinates were obtained for all the network stations and the new coordinates were compared with the previous coordinates of control stations to clarify the extent of their displacement. In this process, different transformation techniques were used. Since the geodetic network that existed in the area and the viaduct were seriously damaged by 3 individual cracks in the NAF the stretching and damage to the viaduct piers was investigated in two sections. The first part from Düzce in the Bolu 
direction to the point where the fault line crack runs under the viaduct and the second part from the crack in the Bolu to Düzce direction. The viaduct region is divided into two parts with pier number 47 taken as the centre point. Therefore, analyses from two directions were examined to pier 48 from Düzce and to pier 46 from Bolu. 28 object points were measured on each of the piers to determine the extent of the displacement. The viaduct piers were transformed from points that are on viaducts themselves, and displacement of the viaducts was determined at the measured points (Ayan and Çelik, 2000).

Then FEM models of the viaducts were prepared using SAP2000 software (SAP2000, 2004; Wilson, 2002). The FEM model separates the viaduct into a finite number of sections. Each section has nodal degrees of freedom on its corners. The dynamic equilibrium equation is calculated for each section, and then these equations of motion are combined to write the system equation of motion in matrix form. The locations of the viaducts were modelled according to the fault line. Each viaduct was modelled according to its physical and geometrical properties. The acceleration record of the 1999 Düzce earthquake North-South (N-S) component was applied to the viaducts in the time history domain $(0.01 \mathrm{~s}$ time interval). The maximum displacement response of the viaduct was calculated by FEM and compared with the geodetic measurements. In this context, the main objective was to test the accuracy of engineering design by comparing the calculated displacement responses with the measured values.

\section{Geodetic studies}

The Bolu Viaducts, constructed as part of the Bolu Mountain Pass, is located in North-Central Turkey (Fig. 1). This project was part of the $114 \mathrm{~km}$ long Anatolian Motorway Project running between Gümüssova and Gerede set up to improve the transportation for the west of Bolu province). The estimated cost of the entire project was 1.5 billion US dollars.

At the inception of the project in 1992, a geodetic network was set up to provide data for the construction work. The two earthquakes caused large ruptures and changes to the topography of the project area; the network was split into at least two parts and the whole geodetic network was damaged. The result was that all connections between the control stations were damaged, and the previous network was considered to be unusable and it was essential to establish a new geodetic network to facilitate the continuation of the project. Despite the damage, there was a possibility that the northern or southern part of the network could be used separately if internal consistency between the stations remained. However, the project structure existing in the field would need to be connected to the control stations of the new geodetic network.
Table 1. Transformation from Bolu to Düzce and Düzce to Bolu.

\begin{tabular}{lcl}
\hline Parameter & Value & \multicolumn{1}{l}{ RMS } \\
\hline \multicolumn{4}{l}{ Transformation } & parameters from & Bolu to Düzce \\
\hline Shift dN & $-35.213 \mathrm{~m}$ & $0.0229 \mathrm{~m}$ \\
Shift dE & $-186.482 \mathrm{~m}$ & $0.0229 \mathrm{~m}$ \\
Rotation angle & $-19.442^{\prime \prime}$ & $1.9000^{\prime \prime}$ \\
Scale & $101.435 \mathrm{ppm}$ & $9.2122 \mathrm{ppm}$ \\
\hline Transformation & parameters from & Düzce to Bolu \\
\hline Shift dN & $-33.015 \mathrm{~m}$ & $0.0152 \mathrm{~m}$ \\
Shift dE & $-186.925 \mathrm{~m}$ & $0.0152 \mathrm{~m}$ \\
Rotation angle & $-25.229^{\prime \prime}$ & $1.6950^{\prime \prime}$ \\
Scale & $-41.215 \mathrm{ppm}$ & $8.2172 \mathrm{ppm}$ \\
\hline
\end{tabular}

In order to analyse the damage to the viaducts due to the earthquakes, the 2-D geodetic and 1-D levelling networks were re-measured. Thus, new coordinates for all the network stations were obtained. Thereafter, the relationships with the previous coordinates of the control stations were investigated to clarify the degree of displacement of the control stations.

In order to associate the previous coordinates of the geodetic stations in the area with the new GPS networks, all common stations were subjected to a 2D-Helmert transformation process. The results of such transformation showed that the northern and southern parts had no consistency. Therefore, a different strategy was adopted, transforming the coordinates from East to West and then West to East. The first transformation started from the Bolu side to the Düzce side (East to West). An iterative strategy was applied, so that transformation commenced by including the first 3 geodetic control stations from the Bolu side. Once consistency was achieved, another common station was taken into account in the transformation and new transformation results were obtained. This process was continued until no inconsistent stations remained in the direction from Bolu to Düzce (Ayan and Çelik, 2000).

The results of this transformation process showed that the common geodetic network stations were consistent up to the region where one of the NAF cracks crosses the path of the viaduct. The same transformation strategy was then applied in the Düzce to Bolu direction. In this transformation, the common points also had no consistency in the same region where the crack crossed the viaduct sections. The results of both transformations processes are given in Table 1 .

When the transformation parameters are examined, it is seen that in the East-West (E-W) direction there is approximately a $2 \mathrm{~m}$ horizontal displacement but in the $\mathrm{N}$ $\mathrm{S}$ direction the horizontal displacement is less than a half metre. The difference between the rotation parameters is negligible for such a small area. However, there is a significant scale problem that might occur resulting from the 


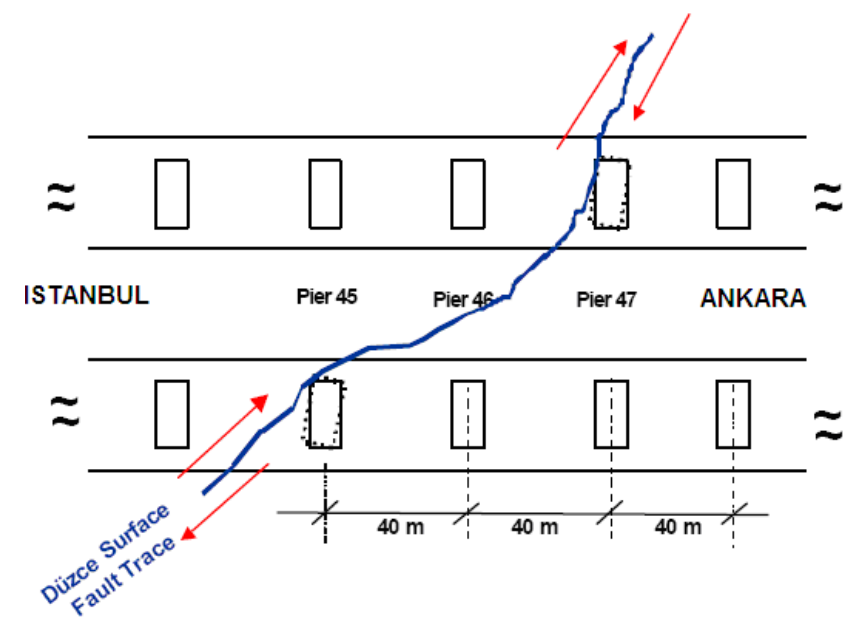

Fig. 4. Fault trace at the viaduct (Ghasemi et al., 2000).

earthquake, the distortion of the national geodetic network, or due to the previous geodetic network processing strategy. Furthermore, there may be projection type confusion, such as Transverse Mercator (TM) or Universal Transverse Mercator (UTM), since the mid-longitude values for both projections are the same for the region.

As mentioned above, the viaduct's previous position within a global system could not be analysed since the viaducts had been seriously damaged by 3 individual cracks on the NAF. These cracks occur between pier 1 to 35 , pier 36 to 47 and pier 48 to 57 but movement in the NAF split the geodetic network into two main parts. The first part is from pier 1 to 47 in the Düzce to Bolu direction and the second part is from pier 57 to 48 in the Bolu to Düzce direction. In this study, the damage and stretch to the viaduct piers had to be investigated in two parts; in the direction from the Düzce to Bolu to pier 48 from pier 1 and from Bolu to Düzce from pier 57 to 46 . Figure 4 shows the fault trace and the location of the relevant viaduct piers. Moreover, the control points on a pier, which were used to determine the transformation, are shown in Fig. 5.

Firstly, the Düzce to Bolu part of the viaduct was considered and, since no transformation effects were carried from the geodetic network, the viaduct piers were transformed from the points on the structures. This entailed a local investigation solely for the viaduct in which the main goal was to identify the relative positional movements of the piers with respect to each other using pier by pier transformations for these transformations, mainly the project and measured coordinates of points at the bottom of the corners of the piers (numbered 5, 6, 17 and 18 in Fig. 5) were used. When these points were not available, the points numbered 1, 2, 3 and 4 were used for the transformation process to reveal the displacements that occurred during the earthquakes (Ayan and Çelik, 2000).

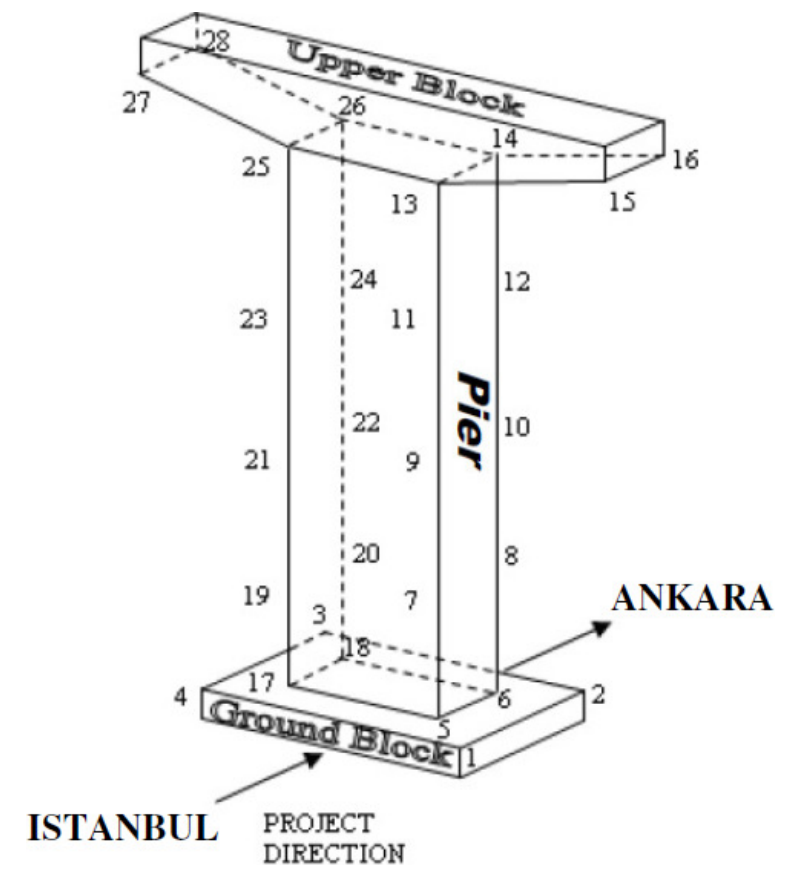

Fig. 5. Control points on the viaduct.

The transformations commenced from pier 1 left and right and were carried out for all the successive piers to number 48 in the Düzce to Bolu direction. For piers 1 to 35 the transformation parameters and the minimum and maximum residuals are given in Tables 2 and 3, respectively. It can be seen that the 18th point of pier 6 on the left hand side has the lowest residual with $0.60 \mathrm{~cm}$. The maximum residual value is on the 3rd point of pier 26 on the right hand side; at $10.54 \mathrm{~cm}$. Piers 1 to $11,13,21,29$ and 35 had consistency within $2 \mathrm{~cm}$. According to the transformation results, the positional consistency of piers 25 to 36 from Düzce to Bolu, remained within $10 \mathrm{~cm}$. The maximum and minimum residual values were found on piers 26 and 25 at 10 and $2 \mathrm{~cm}$, respectively.

The last transformation for the Düzce to Bolu part of the viaduct was performed between the piers 36 to 47 . The Transformation parameters and the minimum and maximum residuals for this section are given in Tables 4 and 5 respectively. At the end of this transformation, the positional consistency stayed within $15 \mathrm{~cm}$. The maximum residual occurred at the 3 rd point of pier 47 on the left hand side, with a value of $15 \mathrm{~cm}$. These residual values do not indicate any structural deformation on the piers.

These results show the positional movements of the piers in relation to each other. As the second stage, the same transformation strategy was applied from the Bolu to Düzce direction. The transformation parameters and the minimum and maximum residuals for this section are given in Tables 6 and 7, respectively. At the end of this transformation, it was seen that the piers from 57 to 49 had a positional consistency (Ayan and Çelik, 2000). 
Table 2. Transformation parameters from Düzce to Bolu, piers 1 to 35 .

\begin{tabular}{lll}
\hline Parameter & Value & RMS \\
\hline Shift dN & $-33.385 \mathrm{~m}$ & $0.0007 \mathrm{~m}$ \\
Shift dE & $-186.815 \mathrm{~m}$ & $0.0007 \mathrm{~m}$ \\
Rotation angle & $-14.629^{\prime \prime}$ & $0.4647^{\prime \prime}$ \\
Scale & $-78.295 \mathrm{ppm}$ & $2.2530 \mathrm{ppm}$ \\
\hline
\end{tabular}

Table 3. Minimum and maximum residuals obtained from the transformation from Düzce to Bolu, piers 1 to 35 .

\begin{tabular}{llllr}
\hline Residual & System A & System B & dE & \multicolumn{1}{c}{$\mathrm{dN}$} \\
\hline Minimum & $06 \mathrm{~L} 18$ & $06 \mathrm{~L} 18$ & $-0.0060 \mathrm{~m}$ & $0.0001 \mathrm{~m}$ \\
Maximum & $26 \mathrm{R} 3$ & $26 \mathrm{R} 3$ & $-0.0553 \mathrm{~m}$ & $-0.1054 \mathrm{~m}$ \\
\hline
\end{tabular}

Through geodetic measurements, the displacements of 28 object points, shown in Fig. 5, were determined. In the FEM, the maximum displacement on the upper block shown in Fig. 5 was determined. For model comparison, the maximum displacements on upper block obtained by geodetic measurements were taken into account. In the following sections, the finite elements method and model comparisons are discussed.

\section{Engineering studies}

The Bolu Viaduct consists of two parallel bridges carrying east and west bound traffic connecting the highway to the Bolu tunnel. The Ankara eastbound bridge has 58 spans and the Istanbul westbound bridge has 59 spans with each span being approximately $39.2 \mathrm{~m}$ long. A general view of the Bolu Viaduct is shown in Fig. 2. The superstructure consists of seven lines of supported, prestressed-concrete box girders seated on sliding pot bearings with a stainless steel-polytetrafluoroethylene (PTFE) slider interface. The deck slab is continuous over 10-span modules with expansion joints between the modules to accommodate thermal movement. The piers for the viaduct are single, castin-place, hollow-core, reinforced concrete columns with a rectangular cross-section (slightly modified by architectural detailing). The columns are $4.5 \mathrm{~m}$ by $8.0 \mathrm{~m}$ in plan and their heights vary from 10 to $49 \mathrm{~m}$. The piers rest on massive reinforced concrete footings supported by twelve $1.8 \mathrm{~m}$ diameter cast-in-drilled-hole (CIDH) reinforced concrete piles bearing on alluvium with an average depth of about $30 \mathrm{~m}$ (Ghasemi et al., 2000; Calvi et al., 2001; Barr et al., 2001).
Table 4. Transformation parameters from Düzce to Bolu, piers 36 to 47 .

\begin{tabular}{lcc}
\hline Parameter & Value & RMS \\
\hline Shift dN & $-34.062 \mathrm{~m}$ & $0.0142 \mathrm{~m}$ \\
Shift dE & $-187.031 \mathrm{~m}$ & $0.0142 \mathrm{~m}$ \\
Rotation angle & $50.396^{\prime \prime}$ & $19.6485^{\prime \prime}$ \\
Scale & $-1299.745 \mathrm{ppm}$ & $95.1349 \mathrm{ppm}$ \\
\hline
\end{tabular}

Table 5. Minimum and maximum residuals obtained from the transformation from Düzce to Bolu, piers 36 to 47 .

\begin{tabular}{llllr}
\hline Residual & System A & System B & dE & \multicolumn{1}{c}{$\mathrm{dN}$} \\
\hline Minimum & $36 \mathrm{R} 2$ & $36 \mathrm{R} 2$ & $0.0814 \mathrm{~m}$ & $-0.0022 \mathrm{~m}$ \\
Maximum & $47 \mathrm{~L} 3$ & $47 \mathrm{~L} 3$ & $0.0592 \mathrm{~m}$ & $0.1520 \mathrm{~m}$ \\
\hline
\end{tabular}

Table 6. Transformation parameters from Bolu to Düzce, piers 57 to 49 .

\begin{tabular}{lcc}
\hline Parameter & Value & RMS \\
\hline Shift dN & $-35.452 \mathrm{~m}$ & $0.0013 \mathrm{~m}$ \\
Shift dE & $-186.704 \mathrm{~m}$ & $0.0013 \mathrm{~m}$ \\
Rotation angle & $-29.721^{\prime \prime}$ & $2.2753^{\prime \prime}$ \\
Scale & $-94.448 \mathrm{ppm}$ & $11.0299 \mathrm{ppm}$ \\
\hline
\end{tabular}

Table 7. Minimum and maximum residuals obtained from the transformation from Bolu to Düzce, piers 57 to 49.

\begin{tabular}{llllr}
\hline Residual & System A & System B & dE & \multicolumn{1}{c}{$\mathrm{dN}$} \\
\hline Minimum & $56 \mathrm{~L} 18$ & $56 \mathrm{~L} 18$ & $-0.0019 \mathrm{~m}$ & $-0.0023 \mathrm{~m}$ \\
Maximum & $50 \mathrm{R} 2$ & $50 \mathrm{R} 2$ & $-0.0147 \mathrm{~m}$ & $0.0153 \mathrm{~m}$ \\
\hline
\end{tabular}

The FEM analysis focused on the displacement response of the Bolu Viaducts superstructure to the 1999 Düzce earthquake. In the Ankara direction, the $2.3 \mathrm{~km}$ long viaduct crosses the surface fault rupture as shown in Fig. 4. A post-earthquake investigation at the viaduct site revealed that the fault intersects the viaduct (between piers 44 and 45) at an angle of about $25^{\circ}$, and the magnitude of the ground dislocation in the fault-parallel direction across the rupture was approximately $1.5 \mathrm{~m}$. To understand the dynamic behaviour of the viaduct under earthquake conditions in the time history domain, a FEM modelling was implemented and the ground motion recorded at the Bolu station during the 1999 Düzce earthquake was used. The seismic performance of the Bolu viaducts was investigated by Park et al. (2004) who studied the responses of passive control devices installed in the viaducts. When the earthquake occurred, the 


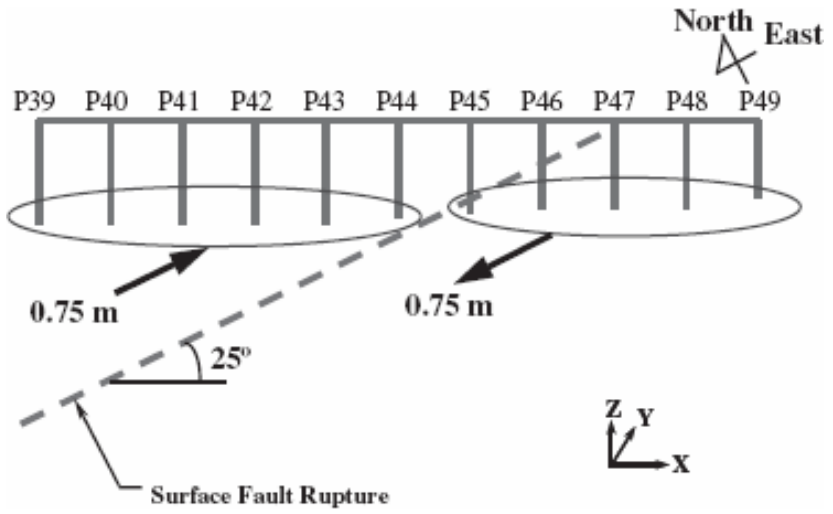

Fig. 6. Orientation of the surface fault rupture and the direction of static ground displacement (Park et al., 2004).

construction of the highway, including the viaducts, was not yet completed. Therefore, the performance of the viaducts has been studied as individual structures as well as considering them as part of the whole system.

The location of the viaducts in relation to the axis of the surface fault rupture is shown in Fig. 6. The permanent differential ground displacement across the surface rupture was recorded as approximately $5 \mathrm{~m}$ near the epicentre and $1.5 \mathrm{~m}$ where it crossed the Bolu Viaduct at piers 45 and 47 as shown in Fig. 4 (Park et al., 2004). The peak ground accelerations recorded at the Bolu and Düzce stations were $0.81 \mathrm{~g}$ and $0.51 \mathrm{~g}$, respectively, which are much higher than the design value of $0.4 \mathrm{~g}$ (Barka et al., 2000). The acceleration response spectra for these two recordings are significantly in excess of the design spectra given by the American Association of State Highway and Transportation Officials (AASHTO) over a considerable range of periods. The viaduct was designed according to the AASHTO criteria with $A=0.4$ (design acceleration for 500 years period) and $S=1.2$ (design spectrum constant) (AASHTO, 1991).

The finite element time history analysis of reinforced concrete viaducts under earthquake loading can be a powerful tool for predicting their seismic performance. It is also possible to compare the FEM results with geodetic measurements to assess the efficiency and reliability of the numerical results. The FEM assumes that the main body considered is separated into a finite number of elements (Zienkiewizc, 1997). In this study the finite element package software, SAP2000 (SAP2000, 2004; Wilson, 2002) was used for numerical analysis. It is a stand-alone finite-element-based structural program for the analysis and design of engineering structures. The viaduct superstructure and piers were modelled using 3-D shell elements, and the foundation condition at each footing is modelled as finite springs. The structural and foundation elements were assumed to follow a linear elastic material mode of behaviour.

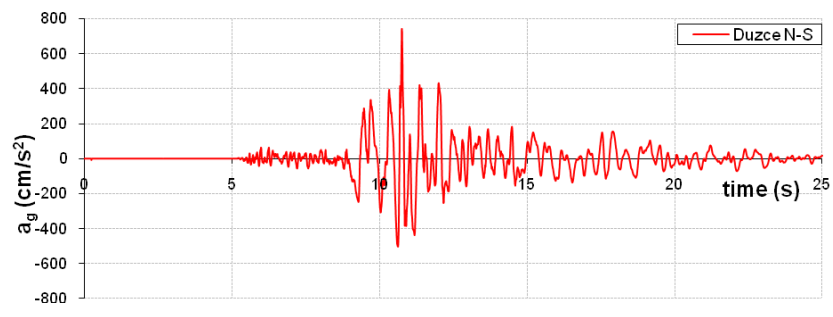

Fig. 7. Acceleration record of the 1999 Düzce earthquake N-S component.

The dynamic equation of motion is given in terms of an effective loading as follows (Clough and Penzien, 1995):

$$
[\mathbf{K}]\{u(t)\}+[\mathbf{C}]\{\dot{u}(t)\}+[M]\{\ddot{u}(t)\}=\left\{p_{\text {eff }}(t)\right\}
$$

where $[\mathbf{K}]$ is the stiffness matrix; $[\mathbf{C}]$ is the proportional damping matrix; $[\mathbf{M}]$ is the diagonal mass matrix; $\{u(t)\}$, $\{\dot{u}(t)\}$, and $\{\ddot{u}(t)\}$ are respectively the relative displacements, velocities, and accelerations with respect to the ground, and $p_{\text {eff }}(t)$ is the effective load in Eq. (1). If the load includes ground acceleration, the displacements, velocities, and accelerations are relative to this ground motion. Equation (2) represents the freefield input acceleration applied at the base of the structure; the negative sign has little significance in earthquake response analysis and is generally ignored The base acceleration expression for effective loading, $p_{\text {eff }}(t)$, is shown in Eq. (2) as a term of mass and earthquake ground motion (Clough and Penzien, 1995).

$\left\{p_{\text {eff }}(t)\right\}=-[\mathbf{M}]\left\{\ddot{u}_{\mathrm{g}}(t)\right\}$

Since acceleration loads are used, the displacements, velocities, and accelerations computed by Eq. (1) are all measured relative to the ground. The time functions associated with the acceleration loads $\left[m_{\mathrm{x}}\right],\left[m_{\mathrm{y}}\right]$, and $\left[m_{\mathrm{z}}\right]$, are the corresponding components of uniform ground accelerations $\left\{\ddot{u}_{\mathrm{gx}}\right\}$, and $\left\{\ddot{u}_{\mathrm{gy}}\right\},\left\{\ddot{u}_{\mathrm{gz}}\right\}$ which were taken from the Düzce 1999 earthquake acceleration record. Only the translational components of the Düzce earthquake were employed for numerical analysis as shown in Fig. 7 (Barka et al., 2000).

The peak ground acceleration (PGA) measured on site was $0.8 \mathrm{~g}$ and $0.5 \mathrm{~g}$. Columbia and Paris Universities declared that they measured a PGA of about 1.0-1.1 g based on data obtained from their stations located in Karadere on the other side of fault. This value is much more than the design value as shown in Fig. 8 (Yilmaz and Türer, 2002).

The typical view of viaduct pier is shown in Fig. 9. The FEM structural model of the piers was analyzed by SAP2000 software in a time history domain using real ground motion acceleration data (1999 Düzce N-S record) (SAP2000, 2004; Wilson, 2002). The model is can be seen in Fig. 10. The area of section is taken as $14.50 \mathrm{~m}^{2}$, the area of floor is taken to be $13.00 \mathrm{~m}^{2}$ and the mass on each pier is assumed 


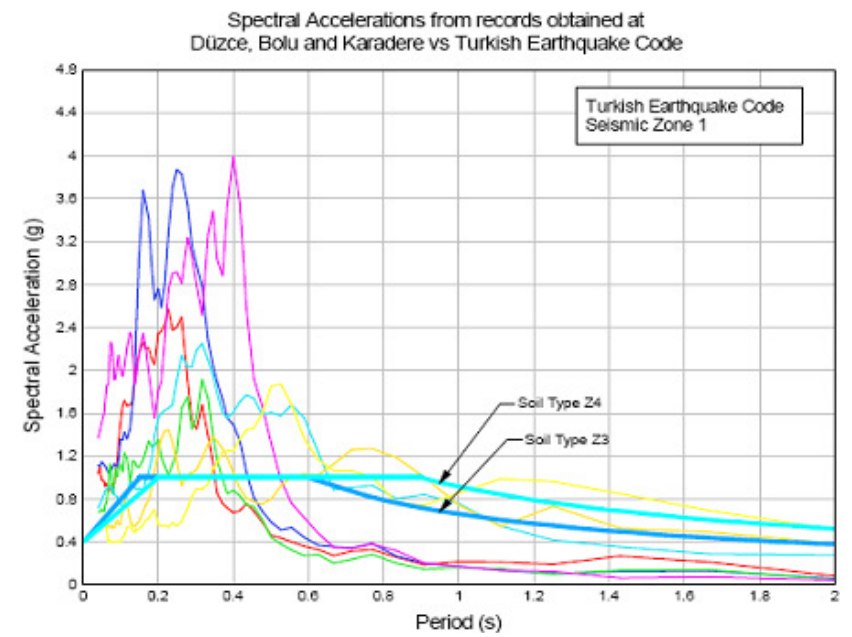

Fig. 8. The comparison of spectrum between Turkish Earthquake Code and site data.

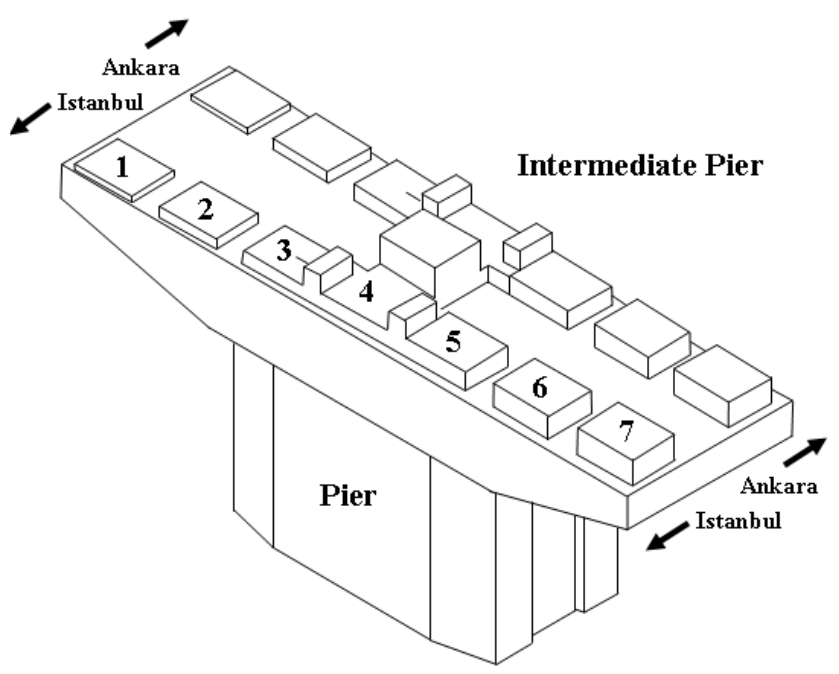

Fig. 9. Typical view of viaduct pier.

to be 400 ton. In order to analyse each pier 11164 joints and 10900 shell elements were used. A single pier was analysed as a single model because the piers are connected to each other by pinned supported traverses. In addition when earthquake happened the road was under construction. This is why the effect of pier to neighbouring pier was not considered. The analysed meshed shape of the viaduct pier can also be seen in Fig. 10. Other parameters such as the dimension and height of pier, the distance of the pier to the fault line are also taken into account using the "scale factor" tool of the software.

Each viaduct pier has its own characteristics and design parameters. Although their main properties such as shape, material, construction system and workmanship are similar local conditions for the viaduct piers vary. The general characteristics of the piers are given as cross-section
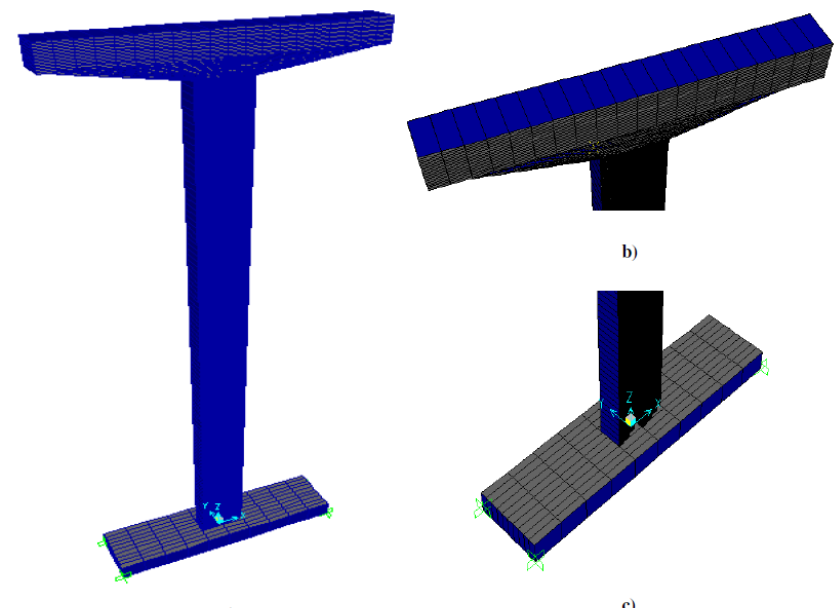

Fig. 10. Structural analysis model of a viaduct pier (a) general, (b) top, (c) base view.

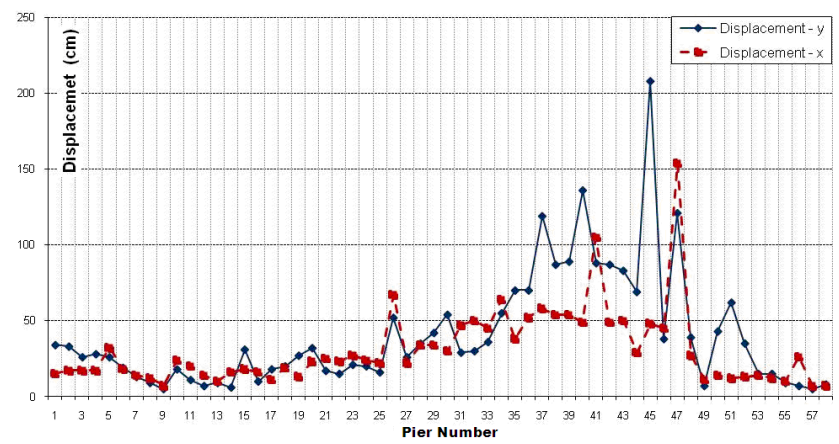

Fig. 11. The measured peak displacements of the viaduct piers in $\mathrm{x}$ - and $\mathrm{y}$-directions caused by the Düzce earthquake.

area $=14.30 \mathrm{~m}^{2}$, moments of inertias (longitudinal) $38.30 \mathrm{~m}^{4}$ and $106.30 \mathrm{~m}^{4}$, modulus of elasticity for reinforced concrete $=2.85 \times 10^{10} \mathrm{~N} \mathrm{~m}^{-2}$, and self weight $=25000 \mathrm{~N} \mathrm{~m}^{-3}$.

The measured response of the viaduct piers in $\mathrm{x}$ and $\mathrm{y}$ directions during the Düzce earthquake is given in Fig. 11. As shown in this figure, the peak displacement in the ydirection occurs in pier 45, which is the closest to the fault line. The maximum response in the $\mathrm{x}$-direction was measured in pier 47. The maximum displacement response values in the $y$-direction are generally larger than the values in the $\mathrm{x}$-direction. Here $\mathrm{y}$ is parallel to $\mathrm{E}-\mathrm{W}$ and $\mathrm{x}$ is parallel to $\mathrm{N}-\mathrm{S}$ direction.

The measured displacement response values decrease in proportion to the distance from the fault line. The maximum displacements of piers close to the fault line are larger than the piers far from fault line. Figure 12 provides a comparison of the geodetically measured and numerically calculated peak pier displacements in the x-direction. The figure shows that the measured values are generally larger than the calculated values. 


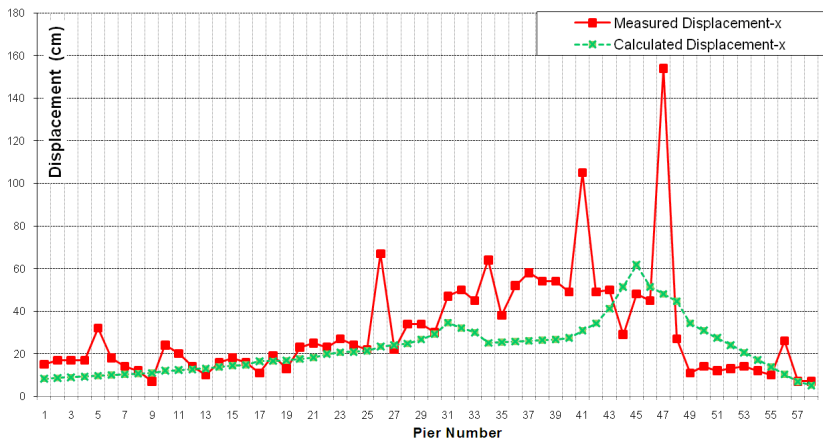

Fig. 12. Comparison of the measured and calculated peak displacements of the viaduct piers in the $\mathrm{x}$-direction caused by the Düzce earthquake.

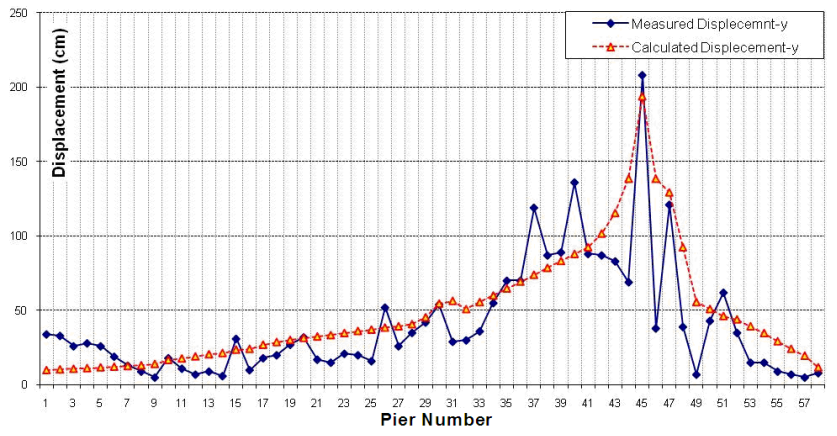

Fig. 13. Comparison of the measured and calculated peak displacements of the viaduct piers in the y-direction caused by the Düzce earthquake.

In Fig. 13 a pattern similar to that shown in Fig. 12 can be observed. The viaduct piers close to the fault line responded more than the others. The calculated values do not change dramatically, but the measured values do. This is because the parameters taken into account in the analysis are limited to the material parameters, dimensions and height of the viaduct piers, the distance of pier location to fault line, ground motion parameters which are why it cannot perfectly reflect the real case. However, especially in the $y$-direction, the calculated values are not too very different from the measured values. These considerably logical results are obtained from the numerical analysis which is compared to the results obtained from the geodetic method.

\section{Conclusions}

Roads and viaducts situated in eastern Marmara region were seriously damaged by the 1999 Izmit/Kocaeli and Düzce earthquakes. In this work, the displacements that occurred in the Bolu viaducts after the Düzce earthquake were determined in detail by geodetic measurements such as GPS, total stations and levelling. Since it was not possible to restore the damaged parts of structures back to their previous positions after determining the status of the viaducts, a rehabilitation project was implemented. In this study, the damage incurred from the displacements of the object points that were embedded on the piers so the deformation on the body of the piers and the displacements of the piers are considered.

Displacements of the components of the viaducts were geodetically measured. In addition, these displacements were also calculated by numerical simulation of earthquake ground motion using the FEM method. The geodetically measured values are real, so the calculation results should close to these values.

The measured and calculated peak pier displacements both increase on those piers that are located closer to the surficial trace of the NAF. The mismatch between observed and predicted motion decreases in average with the distance from the fault line. Since near the fault trace the horizontal displacement field is discontinuous and large inelastic deformation is expected, the behaviour of the part of the structure in this location cannot easily be reproduced by FEM simulations. Indeed, the applied model loads are derived from source acceleration spectra that cannot take into account localized finite deformation effects. Therefore, the piers that are closer to the fault line need higher safety factors in the engineering design calculations. In order to obtain a better engineering analysis, it is necessary to obtain more parameters for the numerical analysis, including local soil conditions, distance to fault line and, velocity of $\mathrm{S}$ and $\mathrm{P}$ waves.

The numerical simulations indicate that the design parameters are insufficient which the piers although did not collapse there was serious damage caused by the 1999 Düzce earthquake. These piers were designed and constructed to codes in which the recurrence period of the largest earthquake is considered to be about 475-500 years however, this is inadequate. It is necessary to design viaduct pier using a 2000 year earthquake recurrence period. In addition, the PGA design value was $0.4 \mathrm{~g}$ according to AASHTO, however, the recorded PGA at the Bolu and Düzce stations were $0.81 \mathrm{~g}$ and $0.51 \mathrm{~g}$, respectively, which were much higher than the design value.

Furthermore, the design philosophy of the viaduct should be revised. These types of main roads should be able to continue functioning immediately after a severe earthquake. Even though after the Düzce earthquake none of the piers had totally collapsed or were heavily damaged had the road been open it would not have been possible to allow vehicles to access the road until a full inspection had been carried out of the moderate damage incurred. Thus, this lack of functionality after the earthquake will not only result in economic losses but could also hamper access by emergency services to areas affected by the earthquake. Therefore, it is imperative that a performance based design philosophy is implemented for such structures to enable them to continue functioning after a serious earthquake. 
The eastern Marmara region has a high level of seismic risk therefore, it is vital that viaducts, roads and other elements of the transportation infrastructure be continuously monitored continuously to detect all possible future deformations in order to reliably assess the seismic hazard and predict the seismic behaviour of these most important engineering structures.

Acknowledgements. The authors would like to thank "LEICA Sistem Bilgisayar ve Teknik Hizmetler San. A.Ş." for providing GPS receivers, total stations and levels. The authors are also grateful for the valuable comments about the study from Ronnie Kamai and an anonymous referee.

Edited by: O. Katz

Reviewed by: two anonymous referees

\section{References}

AASHTO: Standard Specifications for Highway Bridges, Division I-A: Seismic Design, The American Association of State Highway and Transportation Officials, Washington, DC, 1991.

Akyüz, H. S., Hartleb, R., Barka, A., Altunel, E., Sunal, G., Meyer, B., and Armijo, R.: Surface rupture and slip distribution of the 12 November 1999 Düzce earthquake (M 7.1), North Anatolian Fault, Bolu, Turkey, B. Seismol. Soc. Am., 92, 61-66, 2002.

Ambraseys, N. N.: Engineering Seismology, Earthq. Eng. Struct. D., Suppl. F662, 17, 1-105, 1988.

Ambraseys, N. N.: The Seismic Activity of the Marmara Sea Region over the last 2000 Years, B. Seismolol. Soc. Am., 92, 1-18, 2002.

Ambraseys, N. N. and Finkel, C. F.: The Seismicity of Turkey and Adjacent Areas: A Historical Review, 1500-1800, Muhittin Salih EREN, Istanbul, 240 pp., 1995.

Armijo, R., Meyer, B., Hubert, A., and Barka, A.: Westward Propagation of the North Anatolian Fault into the Northern Aegean: Timing and Kinematics, Geology, 27, 267-270, 1999.

Ayan, T. and Çelik, R. N.: Gümüova Gerede Motorway Measurement and Analysis Report, Technical Report, ITU Civil Engineering Faculty Geodesy Department, Istanbul, 2000.

Barka, A.: Slip Distribution Along the North Anatolian Fault Associated with Large Earthquakes of the Period 1939 to 1967, B. Seismol. Soc. Am., 86, 1234-1238, 1996.

Barka, A.: The 17 August 1999 Izmit Earthquake, Science, 285, 1858-1859, 1999.

Barka, A., Kozaci, O., Akyüz, S., and Altunel, E. (Eds): The 1999 Izmit and Düzce earthquakes: Preliminary results, Istanbul Technical University, Istanbul, 2000.

Barr, J. M., Sanders, P. A., and Davey, S. J.: Effect of the Kocaeli $(\mathrm{Mw}=7.4)$ and Düzce $(\mathrm{Mw}=7.2)$ earthquakes on seismically isolated viaducts on the Istanbul to Ankara Motorway, Turkey, in: Proceedings of the 5th World Congress on Joint, Bearings and Seismic Systems for Concrete Structures, Rome, Italy, 7-11 October 2001.

Bozkurt, E.: Neotectonics of Turkey-A Synthesis, Geodin. Acta, 14, 3-30, doi:10.1016/S0985-3111(01)01066-X, 2001.
Calvi, G. M., Priestley, M. J. N., and Germani, G.: Bearing and isolation systems for a long viaduct crossing an active fault, in: Proceedings of the 7th International Seminar on Seismic Isolation, Passive Energy Dissipation and Active Control of Vibrations of Structures, Assisi, Italy, 2-5 October 2001.

Clough, R. W. and Penzien, J.: Dynamics of Structures, 3rd edn., Computers \& Structures, Inc., Berkeley, CA, USA, 1995.

Çelik, R. N., Acar, M., Kaplan, M. O., and Ayan, T.: Investigation of Displacement in Engineering Structures after Earthquakes Using both Conventional and Satellite Geodetic Techniques, in: Proceedings of International Symposium on Modern Technologies, Education and Professional Practice in Geodesy and Related Fields, Sofia, Bulgaria, 4-5 November 2004.

Çelik, R. N., Acar, M., Kaplan, M. O., and Ayan, T.: Benefits of Using Geodetic Approaches for Determining Earthquake Damages on Large Structures, in: Proceedings of International Symposium on Modern Technologies, Education and Professional Practice in Geodesy and Related Fields, Sofia, Bulgaria, 3-4 November 2005.

Ghasemi, H., Cooper, J. D., Imbsen, R., Piskin, H., Inal, F., and Tiras, A.: The November 1999 Düzce Earthquake: Post-Earthquake Investigation of the Structures on the TEM, Technical Report, Federal Highway Administration, U.S. Department of Transportation, Washington, DC, Publication No. FHWA-RD-00-146, 2000.

Park, S. W., Ghasemi, H., Shen, J., Somerville, P. G., Yen, W. P., and Yashinsky, M.: Simulation of the seismic performance of the Bolu Viaduct subjected to near-fault ground motions. Earthq. Eng. Struct. D., 33, 1249-1270, 2004.

SAP2000: Structural Analysis Program. Nonlinear Version 9.0, Computers and Structures Inc., Berkeley, CA, 2004.

Tibi, R., Bock, G., Xia, Y., Baumbach, M., Grosser, H., Milkereit, C., Karakisa, S., Zünbül, S., Kind, R., and Zschau, J.: Rupture Processes of the 1999 August 17 Izmit and November 12 Düzce (Turkey) Earthquakes, Geophys. J. Int., 144, F1-F7, 2001.

Wessel, P. and Smith, W. H. F.: Free software helps map and display data, EOS T. Am. Geophys. Un., 72(41), 441, 445-446, 1991.

Wessel, P. and Smith, W. H. F.: New version of the Generic Mapping Tools released, EOS T. Am. Geophys. Un., 76(33), 329 pp., 1995a.

Wessel, P. and Smith, W. H. F.: New version of the Generic Mapping Tools released, EOS T. Am. Geophys. Un., electronic supplement, available at: http://www.agu.org/eos_elec/95154e. html, 1995 b.

Wessel, P. and Smith, W. H. F.: New, improved version of Generic Mapping Tools released, EOS T. Am. Geophys. Un., 79(47), 579 pp., 1998.

Wilson, E. L.: SAP2000. Three-Dimensional Static and Dynamic Analysis of Structures A Physical Approach With Emphasis on Earthquake Engineering, 3rd edn., Computers and Structures Inc., Berkeley, CA, 2002.

Yilmaz, Ç. and Türer, A.: ECAS2002 Uluslararasi Yapi ve Deprem Mühendisliği Sempozyumu, Ankara, Türkiye, Orta Doğu Teknik Üniversitesi, 14 Ekim 2002 (in Turkish).

Zienkiewizc, O. C.: The Finite Element Method in Engineering Sciences, 3rd edn., McGraw-Hill, New York, 1977. 